\title{
International Arbitration and Public Policy Issues in the Indian Subcontinent: A Look through the English Common Law and International Lenses
}

\author{
AFM Maniruzzaman* and Ijaz Ali Chishti**
}

\begin{abstract}
Public policy is an important issue in the context of international arbitration and, for that matter, domestic arbitration. However, in respect of the former there appears to be progressively a more restrictive approach applied globally than in the latter. Since the public policy issues could prove to be a stumbling block to the recognition or enforcement of a foreign arbitral award in the concerned country's courts, an international arbitral tribunal should be mindful of the matter, though challenging, while rendering the award. The best guide for an international arbitral tribunal would be to look into the recognising or enforcing country's law and practice in the context. The article is concerned with the public policy issues for the recognition or enforcement of foreign arbitral awards in the three major countries of the Indian subcontinent such as India, Pakistan and Bangladesh. These countries have historically had the common heritage of the English common law system which influences their respective laws, court decisions and jurisprudence. Thus, the article examines the public policy issues in the context of international arbitration in these countries in light of the English common law and international arbitration law and practice so that international arbitrators could draw upon the findings of the study while rendering arbitral awards, and when it is so relevant.
\end{abstract}

\section{INTRODUCTION}

Public policy is understood by the modern world in two different contexts, i.e., in the political context and in the legal context. Public policy in the political context can be termed as 'Policy of a Government'. ${ }^{1}$ Public policy in the legal context, in legal scholarship and in courts'

\footnotetext{
* Professor AFM Maniruzzaman is Chair in International and Business Law, Portsmouth Law School, University of Portsmouth, United Kingdom.

${ }^{* *}$ Dr Ijaz Ali Chishti is Visiting Scholar/Postdoc Fellow, Portsmouth Law School, University of Portsmouth, United Kingdom and Court Associate, the Supreme Court of Pakistan.

${ }^{1}$ Central Inland Water Transport Corporation Limited and Anr. v. Brojo Nath Ganguly and Anr, 1986 AIR 1571. In this case, the Indian Supreme Court in an arbitration matter has held that
}

Public policy, however, is not the policy of a particular government. It connotes some matter which concerns the public good and the public interest. The concept of what is for the public good or in the public interest or what would be injurious or harmful to the public good or the public interest has varied from time to time. 
opinion, can be termed as a public policy of a State. In the first sense, each government of a country in line with, sometimes in deviation from, the manifesto of the ruling political party pursues some policies which may include social welfare, promotion of literacy and economic wellbeing of the people, etc. In the second sense, the public policy of a State, consists of 'mandatory rules emanating from law'2 - taken either from the legislation or precedents of courts drawn upon the underlying cause of the legislation. Only public policy in this sense can overrule private arrangement reached between the parties, avoid applicability of foreign rules, and debar enforcement of judgements and awards rendered in a foreign country. ${ }^{3}$ Arbitration law is concerned with public policy in this sense only. In arbitration, the question of public policy (including mandatory rules) arises in following stages of the proceedings: firstly, at the time of the determination of a dispute by the court or arbitral tribunal; secondly, at the time of challenge to an award before the court of competent jurisdiction; and thirdly, at the time of enforcement of an award before the enforcement court. ${ }^{4}$ Thereby, all the arbitral process, starting from the determination of a dispute to the execution of an award, can be affected by the public policy.

Public policy is an integral part of almost every legal system. Similarly, the U.N. Treaty database search engine reveals that the phrase 'public policy' has been found in more than 6805 international instruments ${ }^{5}$, which unequivocally reflects concerns of participating states for the protection of their public policy.

This article will examine the public policy concept in the Indian subcontinent by focusing on three countries such as India, Pakistan and Bangladesh in the context of international arbitration in light of public policy as it is conceived and applied in the English common law as well as in international arbitration law and practice. The reason for selecting the three countries is their common heritage derived from the English common law. Sections 2-5 of the article will focus on public policy in the English common law and international arbitration law and practice and Section 6 will intensively explore the notion of public policy in the context of

Similarly, the US Court of Appeal for the Second Circuit has also rejected in Parsons and Whittemore Overseas Inc. v. RAKA [508 F.2d 969, 975 (2d Cir. 19740)], the argument that the enforcement of arbitral award should be refused on ground of severance of Egyptian and American relations holding that public policy defence cannot be read as a 'parochial device protective of national political interests' or to enshrine 'the vagaries of international politics under the rubric of public policy'. Thus, it was clearly distinguished from the 'policy of a particular or more governments' to a policy of a country.

${ }^{2}$ Farshad Ghodoosi, 'The Concept of Public Policy in Law: Revisiting the Role of the Public Policy Doctrine in the Enforcement of Private Legal Arrangements', Nebraska Law Review, 2015, 94(3): 685-736; See generally, Farshad Ghodoosi, International Dispute Resolution and the Public Policy Exception (London \& New York: Routledge, 2017); Mohammad Reza Baniassadi, 'Do Mandatory Rules of Public Law Limit Choice of Law in International Commercial Arbitration', International Tax \& Business Lawyer, 1992, 10: 59-84; Pierre Mayer, 'Mandatory Rules of Law in International Arbitration', Arbitration International, 1986, 2(4): 274-93.

3 AFM Maniruzzaman, 'International Arbitration and Mandatory Public Law Rules in the Context of State Contracts: An Overview', Journal of International Arbitration, 1990, 7(3), at 53-54:

Although the party freedom of choice of law is a general principle of private international law and is to be separated in principle, it should operate within the limit imposed by such equally

4 Ibid., at 53. important principles of law or subject to any restraint of public policy.

5 https://search.un.org/results.php?tpl=dist_search\&query=public\%20policy\&lang=en\&tplfilter=data (accessed 31 January 2019). 
international arbitration in the three selected countries in the Indian subcontinent. In Section 7, some conclusions and observations will be made.

\section{Public Policy - A Historical Perspective}

Percy H. Winfield asserts that the concept of public policy existed, irrespective of the fact whether it was used unconsciously or consciously, ${ }^{6}$ even before the introduction of equity system in common law. The judges used to consider the benefit of the public while resorting to new writs. ${ }^{7}$ The Dyer's Case of $1414^{8}$ is considered to be the first case which referred to the concept 'encounter common ley' 9 which means anything prejudicial to community or Commonwealth, is a bedrock of the concept public policy. Knight quotes Coke that "nihil quod inconveniens est licitum: It is better, saith the law, to suffer a mischief that is peculiar to one, than an inconvenience that may prejudice many. ${ }^{10}$ In the same tune, in the case of Mitchel $v$. Reynolds ${ }^{11}$ the court (as per Lord Macclesfield), by employing the concept of public policy invalidated a contract which caused restraint of trade. The Court held, '[T]o obtain the sole exercise of any known trade throughout England, is a complete monopoly, and against the policy of law. ${ }^{12}$ This gave rise to an approach, 'a notion designed to guard against violations of communal values and mores.' In 1750, Lord Hardwicke offered one of the first definitions of public policy that was illuminating: contracts against public policy are of no effect not because either of the parties has been deceived but because they are a 'general mischief' to the public.

The U.S. Supreme Court has held in Hilton v. Guyot that a court may refuse to enforce any foreign judgment that violates a public policy of the court. It has been held that

injure[ing] the public health, the public morals, the public confidence in the purity of the administration of law, or ... undermine the sense of security for individual rights, whether of personal liberty or of private property, which any citizen ought to feel. ${ }^{13}$

Knight concludes that ancient expressions reappear in modern garb of public policy, which dictates that 'no one may contract to do anything that 'may be detrimental to the interests

\footnotetext{
${ }^{6}$ Percy H. Winfield, 'Public policy in the English Common Law', Harvard Law Review, 1928, 42(1): 76: One is the unconscious or half-conscious use of it which probably pervaded the whole legal system when law had to be made in some way or other, and when there was not much statute law and practically no case law at all to summon to the judges' assistance. The other is the conscious application of public policy to the solution of legal problems, whether it bore the name by which it is now known or -was partly concealed under some other designation which, however, really expressed the same thing.

7 Ibid., at 79:

Here we have the paradox that public policy pervades our law and that nobody is aware of its existence. No one talked about "public policy" then, yet when a new writ was approved or a new rule laid down, what else was it in most cases that the judges had in view but the benefit of the public?

8 Y. B. 2 Hen. 5, fol. 5, pl. 26 (1414)

9 W. S. W. Knight, 'Public Policy in English Law', Law Quarterly Review, 1922, 38: 207.

${ }^{10} \mathrm{Ibid}$. Knight writes that this maxim is treated by Pollock C.B. in Egerton v. Brownlow, (1853) 4 E. L. C. p. 144),

as an early expression of the doctrine of public policy.

11 (1711) 24 Eng. Rep. 347 (Q.B.).

12 Ibid.

13159 U.S. 113, 164-65 (1895).
} 
of his own country, or is "repugnant to the interests of the State", or is "injurious to the interests of the public", or is "against the public benefits"., 14

Civil law nations have also since long been recognising comparable 'order public' exceptions to the enforceability of foreign judgment. In addition to it, most private international law treaties and domestic legislation contain public policy as a ground of exception. ${ }^{15}$ Therefore, public policy incorporation in international arbitration is not a contemporary innovative concept, rather an importation and adaptation of already existed concept.

In private international law area, public policy always remained present. Although the Hague Conferences on Private International Law of 1893 did not contain a public policy exception but with the development of international law this concept became more dominant in the twentieth century. It found place in all subsequent documents, both international and regional, e.g., the UNIDROIT Principles of International Commercial Contracts and the UNCITRAL Model Law on Procurement of Goods, Construction and Services, Brussel Convention, Rome Convention, etc. ${ }^{16}$

In the Indian subcontinent the applicability of contract principles was not uniform, since there was no enactment on contract law, therefore, the courts, Mayor's Court in Presidency towns of Calcutta, Madras and Bombay, used to administer cases under the English common and statute law so far as they are applicable to peculiarities of the situation. While the judges in other areas, in absence of any enactment, used to seek guidance 'mainly from the principles of justice, equity and good conscience'. ${ }^{17}$ During the British rule, the contract law was enacted in 1872, hence the title 'The Contract Act 1872'. It is 'largely based on the principles of English law', including that of public policy, which was developed in the English common law, ${ }^{18}$ such as, a contract is void if its considerations and objects are unlawful, it is without consideration, it is for restraint of trade, it is for restrain of legal proceeding, or it is for restraint of marriage, etc. ${ }^{19}$

After independence and partition of India in 1947, both India and Pakistan adopted the same Act — The Contract Act 1872 — and have been applying its provisions in their respective territories till to date. Therefore, any contract which offends these principles is void ab initio. ${ }^{20}$ Similarly, Bangladesh too, after establishing herself as an independent country from Pakistan in 1971, adopted The Contract Act 1872, verbatim, vide the Bangladesh Laws (Revision and Declaration) Act 1973. ${ }^{21}$ Thus, in the Indian subcontinent, under section 23 of The Contract

\footnotetext{
14 Knight, supra note 9.

15 Garry B. Born, International Commercial Arbitration, commentary and material (The Hague: Kluwer Law International and Transnational Publishers, 2001).

16 Ghodoosi, 2017, supra note 2.

17 Agarwala, Contract Act 1872.

18 Ibid.

19 Sections 24 to 30-C of Contract Act, 1872.

20 PLD 1994 Lahore 525, Messers Rupali Polyester Ltd v. Dr Nael G. Bunni and others; PLD 1970 SC 373, N.A. Chawdhury v. M/s. Mitsui O.K. Lines Ltd.

21 Through section 3 and $2^{\text {nd }}$ Schedule of the Bangladesh Laws (Revision and Declaration) Act, 1973 the words 'Bangladesh, Taka and Penal Code' were substituted for the words 'Pakistan or East Pakistan, Rupees or Rs. Pakistan Penal Code' respectively.
} 
Act 1872, any agreement the consideration or object of which is opposed to public policy is void.

\section{Public Policy and International Conventions}

The Geneva Convention on the Execution of Foreign Arbitral Awards was concluded under the auspices of the League of Nations and was signed in Geneva on 26 September 1927 for the purpose of recognising as binding and enforcing an arbitral award made in pursuance of an agreement, whether relating to existing or future differences, covered by the Geneva Protocol on Arbitration Clauses, 1923. ${ }^{22}$ This Convention in its very first Article states that in order to obtain recognition or enforcement, it shall be necessary that the recognition or enforcement of the award is not 'contrary to the public policy or to the principles of the law of the country' in which it is sought to be relied upon. ${ }^{23}$ This Convention, without defining the concept of public policy itself, has put a burden on that party who seeks to recognise and enforce a foreign arbitral award to show that the recognition and enforcement is not contrary to the public policy and principles of the law and Secondly, along with public policy, the phrase 'the principles of the law of the country' has been used which further broadens the scope of the challenge to enforcement.

Article V (2)(b) of the New York Convention 1958 states that the recognition and enforcement of the award may be refused if the competent authority in the country where recognition and enforcement is sought finds that the recognition and enforcement would be contrary to the public policy of that country. This Convention, in view of its Art. XVI(1), is available in five equally authentic language versions. The English term in Article V (b)(2) 'public policy' appears as 'ordre public' in the French text, and as 'ordine publico' in the Spanish text. Therefore, terms 'public policy' and 'ordre public' and 'ordine publico' are synonyms and are so treated in this study.

Article IX (1) (a) of the European Convention on International Commercial Arbitration, 1961 (the European Convention, 1961) states that an arbitration award may be set aside or its recognition or enforcement may be refused on the ground that the arbitration agreement is not valid under the law to which the parties have subjected it, or failing any indication thereon, under the law of the country where the award was made.

The Convention on the Settlement of Investment Disputes between States and Nationals of other States (the 1965 Washington Convention), in Article 54(3), provides that execution of the award shall be governed by the laws concerning the execution of judgments in force in the State in whose territories such execution is sought. So, all the defences against enforcement of a domestic judgment available in a country are available against enforcement of an award under this Convention.

The Convention on Jurisdiction and Enforcement of Judgment in Civil and Commercial Matters (The 1968 Brussels Convention), in Article 27 (1), states that a judgment shall not be

22 Article 1 of The Convention on the Execution of Foreign arbitral Awards, 1927.

${ }^{23}$ Ibid., Article 1(e). 
recognised if such recognition is "contrary to public policy in the State in which recognition is sought'. ${ }^{24}$

The Governments of the Member States of the Organization of American States ${ }^{25}$ concluded the Convention on International Commercial Arbitration on 30 January 1975 at Panama (the 1975 Panama Convention), whose Article 5 (2), reads that the recognition and execution of an arbitral decision may also be refused if the competent authority of the State in which the recognition and execution is requested finds that the recognition or execution of the decision would be contrary to the public policy ('ordre public') of that State.

The rules of Inter-American Convention on Extraterritorial Validity of Foreign Judgments and Arbitral Awards, concluded at Montevideo on 8 May 1979 (commonly known as the Montevideo Convention, 1979) states that foreign judgments, awards and decisions shall have extraterritorial validity in the States Parties if they are not 'manifestly contrary to the principles and laws of the public policy' (ordre public) of the State in which recognition or execution is sought. ${ }^{26}$

The Riyadh Arab Agreement for Judicial Cooperation of 1983 states that recognition of judgments shall be refused, inter alia, on the grounds that if recognition would be in contradiction with the stipulations of the Islamic Shari'ah, the provisions of the constitution, public order, or the rules of conduct of the requested party. ${ }^{27}$

Article 34 (2)(b)(ii) of the UNCITRAL Model Law states that an award may be set aside by the designated court of the country only if the court finds that the award is in conflict with the public policy of that State. Similarly, Article 36(1)(b) of the Model Law provides that the recognition and enforcement of an award may be refused only 'if the court finds that the recognition and enforcement of the award in contrary to the public policy of the country'. The words of the Model Law on the concept of public policy clearly show that it carries the same concept as that of the New York Convention.

The Arab Convention on Commercial Arbitration of 1987 (the 1987 Amman Convention) states, in Article 35, that the Supreme Court of each contracting State must give leave to enforce an award of the arbitral tribunal and the leave may only be refused if this award is contrary to 'public order'.

The Uniform Act on Arbitration law, 1999 of OHADA, ${ }^{28}$ applicable to any arbitration case when the seat of the Arbitral tribunal is in one of the member States ${ }^{29}$, provides in Article 26 that recourse for nullity is only admissible in the case where the arbitral tribunal has violated an international public policy rule of the state signatories of the treaty. Article 31 of it states

\footnotetext{
${ }^{24}$ See also Article 50 of the 1968 Brussels Convention.

25 Organization of American States was established on 30 April 1948 when its charter was signed by the United States and 20 Latin American States. It is headquartered in Washington, DC and 35 independent American States are its members.

${ }^{26}$ Article 2(h) of the Inter-American Convention on Extraterritorial Validity of Foreign Judgments and Arbitral Awards, 1979.

27 There are some other grounds on which the recognition and enforcement is refused. However, those grounds are not relevant to this subject, therefore, are not mentioned.

${ }_{28}$ Available at: www.droit-afrique.com/uploads/OHADA-Uniform-Act-1999-arbitration.pdf (accessed July 2019).

29 Article 1 of the Uniform Act on Arbitration within the Framework of the OHADA Treaty.
} 
that the recognition and exequatur shall be refused where the award is manifestly contrary to international public policy of the member states.

The 2019 Convention on the Recognition and Enforcement of Foreign Judgments in Civil or Commercial Matters ${ }^{30}$ (also known as the 'Judgments Convention'), adopted by the Hague Conference on Private International Law (HCCH) on the 2nd July 2019, provides in Article 7 (1) (c) that recognition or enforcement of a foreign judgement may be refused

if recognition or enforcement would be manifestly incompatible with the public policy of the requested State, including situations where the specific proceedings leading to the judgment were incompatible with fundamental principles of procedural fairness of that State and situations involving infringements of security or sovereignty of that State.

After a brief overview of various conventions with reference to public policy it becomes clear that the concept of public policy is not at issue at all but the scope of public policy may be at issue because in some convention the word 'against the public policy' whereas in some other 'manifestly contrary to the principles and laws of the public policy' and in some others against the 'principles of law' or 'the principles of Shari' ah' have been used.

The UNCITRAL Report on the work of its $18^{\text {th }}$ Session states on the scope of public policy that:

It was understood that the term 'public policy' which was used in the 1958 New York Convention and many other treaties, covered fundamental principle of law and justice in substantive and procedural respects. Thus instances such as corruption, bribery and fraud and similar serious cases would constitute a ground for setting aside an award.

\section{Making of Public Policy}

There are two approaches with regard to the domain of the authority for the crafting of public policy. One approach asserts that it is within the domain and authority of the legislative to craft a public policy. This approach is also termed as passive approach of the court towards assessment of public policy. ${ }^{31}$ This approach is favoured by Justice Burrough who described, in Richardson v. Mellish, public policy as 'a very unruly horse' as 'when you get astride of it, you never know where it will carry you'. ${ }^{32}$ Other proponents include Lord Alderson and Lord Parke who opined in Egerton v. Brownlow. Lord Parke was of the view that it is the legislator, not the parties and the courts, which should determine public good and public policy. ${ }^{33}$ Under this view, with the existence of multitude of statutes, there is no need for judiciary to structure the building of public policy.

\footnotetext{
30 Available at: https://assets.hcch.net/docs/806e290e-bbd8-413d-b15e-8e3e1bf1496d.pdf (accessed July 2019).

31 Ghodoosi, 2017, supra note 2, at 25.

32 Robert F. Brachtenbach, 'Public Policy in Judicial Decisions' (1985-1986) 21 Gonz. L. Rev. 1, 4.

${ }^{33}$ Farshad Ghodoosi, 'Arbitrating Public Policy: Why the Buck Should Not Stop at National Courts', Lewis \& Clark Law Review, 2016, 20: 237. It is now common belief that a government's legislative branch should determine public policy.
} 
The second, a more active approach of the court towards assessment of public policy can be found in an old case of Cooke v. Turner ${ }^{34}$ wherein it had held a condition void when it abstained a party from doing an act which the State had an interest to be done. This view is further buttressed by the opinion of Lord Watson rendered in Nordenfeldt v. Maxim, ${ }^{35}$ stating:

A series of decisions based upon grounds of public policy, however eminent the judges by whom they were delivered, cannot possess the same binding authority as decisions which deal with and formulate principles which are purely legal. The course of policy pursued by any country in relation to, and for promoting the interests of, its commerce must, as time advances and as its commerce thrives, undergo change and development from various causes which are altogether independent of the action of its courts. ${ }^{36}$

Even if public policy falls within the domain of legislature's powers the courts are required to apply public policy principle on each case having most of the time very unique and peculiar facts. Therefore, judges whenever apply this principle on every new case after searching out from the statutes, precedents and other relevant sources, they intentionally or unintentionally venture into the area of policy making. ${ }^{37}$

Since in India, Pakistan and Bangladesh every organ of the state, Legislature, Judiciary and Executive, have by the Constitution a clearly defined domain to work within, and the Constitution has some fundamentals which cannot be infringed even by the Legislature. Therefore, the judiciary does play a very active role towards defining and crafting public policy of the country. In this way, its approach does fall within the second category as a matter of course.

\section{The Nature And Scope of Public Policy}

It is worth noting that in its 2015 Report on the public policy Exception in the New York Convention based on 40 jurisdictions, the International Bar Association (IBA) Subcommittee on Recognition and Enforcement on Arbitral Awards noted that 'whatever the definition adopted, many courts stress that public policy is an ever-evolving concept. ${ }^{38}$ According to the Report, there is a tendency in case law in most countries covered in it to construe public policy in a narrow sense when it comes to be a ground for denying the enforcement of a foreign arbitral award. ${ }^{39}$ It notes:

The level of required violation of public policy varies from one jurisdiction to another: the violation must be "clear", "concreate", "evident" or "patent", "blatant", "manifest",

\footnotetext{
4 (1846) 15 Messon and Welsby's Reports.

35 [1894] AC 535, also available at: www.uniset.ca/other/cs6/1894AC535.html (accessed July 2019).

36 ibid.

37 Ghodoosi, supra note 33. Despite public policy being the legislature's domain, it inevitably arises in judicial cases. Judges often grapple with potential conflicts between private acts and basic public interests as reflected in precedents and communal values, and especially in statutes.

38 Available at: www.ibanet.org/LPD/Dispute_Resolution_Section/Arbitration/Recogntn_Enfrcemnt_Arbitl_Awr d/publicpolicy15.aspx (hereinafter The IBA Report on Public Policy 2015) (accessed July 2019).

${ }^{39}$ See also the ILA Final Report on Public Policy (2002), New Delhi Conference (2002), at para.22.
} 
"obvious and manifest", "flagrant", "particularly offensive", "severe", "intolerable",

"unbearable", "repugnant to the legal order", etc. ${ }^{40}$

It is beyond the scope of this article to discuss in detail the scope of public policy at the global level, ${ }^{41}$ it will suffice to briefly highlight certain aspects of public policy which are pertinent here.

In the context of international arbitration a distinction is drawn between domestic public policy and international public policy and the latter is weighed more heavily by courts in most jurisdictions when it comes to the issue of refusal of enforcement of a foreign arbitral award. ${ }^{42}$ International public policy or 'ordre public international' is always narrower in scope than domestic public policy or 'ordre public interne' in most jurisdictions. The manner or fashion in which these two public policy variants are prescribed in various jurisdictions may be described as the monist or the dualist approach. Under the former approach both international and domestic public policies are considered one and the same whereas under the latter two public policies are stipulated separately such as domestic public policy applying to domestic arbitration and international public policy to international arbitration. One can thus mention the French and Portuguese approaches as dualist ${ }^{43}$ and the $\operatorname{Indian}^{44}$ and Pakistani ${ }^{45}$ approaches as monist. Under English law, the approach appears to have been traditionally monist as well, ${ }^{46}$ but recent case law tends to articulate international public policy distinctly. ${ }^{47}$ It has to be acknowledged that where there is no clear distinction between domestic public policy and international public policy there is a scope for courts to interpret public policy in a broader sense ${ }^{48}$, though not always is necessarily the case. ${ }^{49}$ There is a view, however, that international public policy is indeed a 'misnomer' because it is 'national' for being a sub-category of national

\footnotetext{
40 IBA, supra note 38, at 11. See generally, Anton G. Maurer, The Public Policy Exception under the New York Convention (Revised Ed., JurisNet, LLC, 2013.

${ }^{41}$ See IBA, supra note 38; Anton G. Maurer, The Public Policy Exception Under the New York Convention (Revised Ed., JurisNet, LLC, 2013); and ILA, Interim Report on Public Policy as a Bar to Enforcement of International Arbitral Awards (London Conference, 2000).

42 Van den Berg, 'Refusals of Enforcement under the New York Convention of 1958: the Unfortunate Few', in Arbitration in the Next Decade (ICC Bulletin - 1999 Special Supplement at p.86.

${ }^{43}$ See ILA, supra note 41.

44 See generally, Nakul Dewan (ed.), Enforcing Arbitral Awards in India (LexisNexis, 2017).

45 See generally, Ijaz A. Chisti, Enforcement of Foreign Arbitral Award (Law and Practice of Pakistan) (Manzoor Law Book House, Lahore, 2017).

46 See the ILA, supra note 41, at 13-14, where it has been noted that
}

Although the English courts have not yet expressly mentioned international public policy, they have recently affirmed the importance of finality of awards when considering the objection to enforcement on grounds of illegality, and effectively endorsed a restrictive concept of public policy.

See also IBA Country Report (England) on Public Policy (by Maxi Scherer), available at: www.ibanet.org/LPD/Di sputer_Resolution_Section/Arbitration/Recogntn_Enfrcemnt_Arbitl_Awrd/publicpolicy15.aspx (accessed July 2019).

${ }^{47}$ Honeywell International Middle East Ltd. v. Meydan Group LLC [2014] EWHC 1344 (TCC), 180, where it was noted that for determining whether the award is contrary to public policy under Section 103(3) of the English Arbitration Act, the 'relevant test is English international public policy.' Tamil Nadu Electricity Board v. ST-CMS Electric Company Private Ltd. [2008] 1 Lloyd's Rep 93 at 42: 'in the context of an international treaty, "public policy" means international public policy and differs from public policy in a domestic context.'

${ }^{48}$ See the Indian Supreme Court case Oil \& Natural Gas Corporation Ltd v SAW Pipes Ltd, AIR 2003 SC 2629.

${ }^{49}$ See generally the IBA, supra note 38 and the country reports. 
public policy. It always pertains to a nation and requires its enforcement by the courts of that nation. ${ }^{50}$

Apart from domestic and international public policy, the third dimension of public policy is known as 'transnational public policy' or 'truly international public policy' which is the most restrictive variant of all. It is of 'universal application - comprising fundamental rules of natural law, principles of universal justice, jus cogens in public international law, and the general principles of morality accepted by what are referred to as "civilised nations". ${ }^{51}$ For example, transnational public policy may include, inter alia, the prohibition against 'terrorism, genocide, slavery, smuggling, drug trafficking, bribery and corruption, and paedophilia'. ${ }^{52}$ Although the application of this brand of public policy is not yet extensively noticed in case law, there is a growing support for it in the literature. ${ }^{53}$

Public policy is again classified into two categories, viz., substantive public policy and procedural public policy. ${ }^{54}$ The former is concerned with the subject matter of the award or the merits of the dispute and the latter the procedure through which the dispute is settled. It is difficult to present a uniform list of such substantive and procedural public policies across the broad as there are vagaries of practices in different legal systems - common law, civil law and Islamic law, etc. However, international public policy will be more restrictive and selective, and transnational public policy still more. It is possible that there could also be sometimes some commonality among all the variants of public policy. As regards the public policy at the enforcement stage, international public policy should be meant to be that 'body of principles and rules comprising international public policy of those of the enforcement. ${ }^{, 55}$ For example, if any country considers its policy being based on the Islamic principles, then public policy will consist of only those principles which are fundamentally common among Muslim States. ${ }^{56}$

Among the well-recognized international substantive public policy rules may be enumerated as pacta sunt servanda, equality of creditors in insolvency situations, state immunity, prohibition of punitive damages, and prohibition of excessive interest, etc., which are

\footnotetext{
50 Winnie (Joe-Mei) Ma, 'Recommendations on Public Policy in the Enforcement of Arbitral Awards' (2009) 75 (4) Arbitration; Winnie (Jo-Mei) Ma, 'Public Policy in the Judicial Enforcement of Arbitral Awards: Lessons for and from Australia' (unpublished PhD thesis, 2005, Bond University), available at: https://pure.bond.edu.au/ws/por talfiles/portal/24840462/fulltext.pdf (accessed July 2019).

${ }^{51}$ See ILA supra note 41, at 6-7.

52 Stephen Jagusch, 'Issues of Substantive Transnational Public Policy', in Devin Bray and Heather L. Bray (eds.), International Arbitration and Public Policy (Juris 2015), at 27.

53 Pierre Lalive, 'Transnational (or Truly International) Public Policy and International Arbitration' in Pieter Sanders (ed.), Comparative Arbitration Practice and Public Policy in Arbitration, ICCA Congress Series, 1986 New York, Volume 3 (Kluwer Law International 1987) pp. 258 - 318, available at: www.lalive.law/data/publications/58 _-_Transnational_(or_Truly_International)_Public_Policy_and_International_Arbitration_in_Comparative_Arbit ration_Practice_and_Public_Policy_in_Arbitration_1986.pdf (accessed September 2019); Julian D. M. Lew, 'Transnational Public Policy: Its Application and Effect by International Arbitration Tribunals' (2018), (2016 Hugo Grotius lecture at the CEU Instituto Universitario de Estudios Europas in Madrid), available at: www.idee.ceu.esr/P ortals/0/CIAMEN/Hugo\%20Grocio\%202016.pdf?ver=2018-07-12-141009-723 (accessed September 2019); Margaret Moses, 'Public Policy: National, International and Transnational' (November 12, 2018), available at: http://arbitrationblog.kluwerarbitration.com/2018/11/12/public-policy-national-international-and-transnational/ (accessed September 2019). Audley Sheppard, 'Public Policy and the Enforcement of Arbitral Awards: Should there be a Global Standard', Transnational Dispute Management, 2004, I(1); Jagusch, supra note 52, at 26.

${ }^{54}$ See IBA, supra note 38; ILA, supra note 41.

55 Pierre Mayer and Audley Sheppard, 'Final ILA Report on Public Policy as a Bar to Enforcement of International Arbitral Awards', Arbitration International, 2003, 19(2): 249-63. See Article V(2)(b) of the New York Convention.

56 The Uniform Act on Arbitration law, 1999 of OHADA (see Article 31).
} 
not universal but represent a trend in various jurisdictions. ${ }^{57}$ Examples of international procedural public policy rules could be the right to be heard or of due process, the right to equal opportunity to present one's case, prohibition of obtaining award by fraud or based on falsified documents, breach of other rules of natural justice, etc. ${ }^{58}$

The ILA report (2000) categorizes the international public policy into: (i) fundamental principles pertaining to justice or morality that a State wishes to protect even when it is not directly concerned (ii) rules designed to serve the essential political, social or economic interests of the State, these being known as a mandatory rule (or 'lois de police' in French) and (iii) the duty of the State to respect its obligations towards other States or international organisations. ${ }^{59}$ However, as regards the nature of mandatory rule the report notes, 'every public policy rule is mandatory, but not every mandatory rule forms part of public policy. ${ }^{60}$ There is a debate as to the extent to which an international tribunal should have regard to the possible mandatory rules beyond the place of enforcement of an arbitral award. ${ }^{61}$

Ghodoosi states that public policy consists of three 'intertwined notions', i.e., public interest; public morality; and public security. Public interest notion is concerned with cost and benefit analysis of private legal arrangement vis à vis benefits of the pubic, e.g., anti-trust laws ${ }^{62}$ as undertaken in the case of United States v. Microsoft. ${ }^{63}$ Public morality notion is concerned with the cases where enforcement private legal arrangement would result in infringement of 'established communal morals and values'. This concept is based on Latin maxim, 'ex turpi causa non oritur actio' meaning, 'of an illegal cause there can be no lawsuit. ${ }^{64}$ Third notion 'public security' is concerned with the 'survival of the state'. Court under this concept prohibits a private arrangement which goes against the survival or poses threat to the security of the State, e.g., State's security provision enacted in the USA by Foreign Investment and National Security Act. ${ }^{65}$

In English case law, various public policy issues in the context of enforcement of an arbitral award are addressed such as an award being: (a) obtained by perjury or fraud; (b) tainted by illegality; (c) obtained in breach of the rules of natural justice; (d) unclear as to the

\footnotetext{
57 See IBA, supra note 38.

58 See IBA, supra note 38 and ILA, supra note 41.

59 ILA, supra note 41.

${ }^{60}$ Ibid., at p.18. See also Inter Maritime Management SA v. Russin \& Vecchi, 9 January 1995, repinted in (1997) XXII Yearbook 789.

${ }^{6}$ See Maniruzzaman, supra note 3; Mayer, supra note 2; Baniassadi, supra note 2; Ibrahim M.N. Shehata, 'Application of Overriding Mandatory Rules in International Commercial Arbitration: An Empirical Analysis', World Arbitration and Mediation Review, 2017, 11(4): 383.

62 Ghodoosi, supra note 33.

${ }^{63}$ United States v. Microsoft, 253 F.3d 34, 45 (D.C. Cir. 2001).

${ }^{64}$ Ghodoosi, supra note 33. He catalogues the concepts of the 'most basic notions of morality and justice', 'common sense', common conscience', 'public morals', and 'justice as a pure fountain' under this notation because all these insist that "court should not taint itself by lending help to private acts that are injurious to basic public morality". He also refers to the case of Liebman v. Rosenthal, 57 N.Y.S.2d 875, 877 (N.Y. Sup. Ct. 1945); 59 N.Y.S.2d 148 (N.Y. App. Div. 1945) wherein plaintiff bribed in USD 28,000 the defendant for securing USA's visa in order to escape from the Nazis. The defendant absconded with money. Later on, plaintiff sued the defendant in New York. The defendant took the plea that contract is void on the ground of public policy. But the court held that 'there is no question of public policy involved in a case like this where a man is attempting to save himself from an enemy who has violated all the laws of civilization.'

${ }^{65}$ Ghodoosi, supra note 33.
} 
obligations imposed on the losing party, and also (e) an award that affects the UK's international obligations under a treaty or EU Law. ${ }^{66}$ In Deutsche Schachtbau v. National Oil, the English Court of Appeal observed:

Consideration of public policy can never be exhaustively defined, but they should be approached with extreme caution ... It has to be shown that there is some element of illegality or that the enforcement of the award would be clearly injurious to the public good or, possibly, that enforcement would be wholly offensive to the ordinary reasonable and fully informed member of the public on whose behalf the powers of the state are exercised. ${ }^{67}$

The Indian Supreme Court has laid down three notions of public policy in the case of Renusagar Power Co. Ltd. v. General Electric Co, ${ }^{68}$ i.e., an award being contrary to (i) fundamental policy of Indian law, (ii) the interest of India and (iii) justice or morality. Another notion, i.e., patent illegality (if an award is patently illegal) was added by another judgement rendered in the case of Oil \& Natural Gas Corporation Ltd. Vs. SAW Pipes Ltd ${ }^{69}$ to widen the notion of public policy (irrespective of the difference between domestic and foreign awards). ${ }^{70}$ These notions governing public policy may be and are capable, on proper occasions, of expansion or modification. ${ }^{71}$ Similarly, a wider concept of public policy has been reiterated in the cases of Phulchand Exports Ltd. versus OOO Patriot, ${ }^{72}$ and Penn Racquet Sports v. Mayor International Ltd. ${ }^{73}$ The Indian Supreme Court in the case of Oil \& Natural Gas Corporation Ltd. $v$ SAW Pipes $L t d^{74}$ has also identified the sources of public policy, by stating

lacking precedent the Court has to give its meaning in the light and principles underlying the Arbitration Act, Contract Act and Constitutional provisions (including Fundamental Rights and Directive Principles) in deciding any case...

The judgment states that public policy can be searched out of the following documents of the respective State: Constitution; Precedents of the superior courts; Principles of the Arbitration Act; Principles of the Contract Act. This judgement did not provide comprehensive

\footnotetext{
${ }^{66}$ See IBA, supra note 46; See also Robert French, 'Arbitration and Public Policy' (2016 Goff Lecture) Asia Pacific Law Review, 2016, 24(1): 1.

${ }^{67}$ Deutsche Schachtbau- und Tiefbohrgesellschaft mbHv. Ras Al Khaimah National Oil Co., Shell Int'l Petroleum Co. Ltd., Court of Appeal, 24 March 1987 [1987] 2 Lloyd's Law Rep. 246, per Sir John Donaldson MR (reversed on other grounds by the House of Lords [1990] 1 AC 295). See also Minmetals v. Ferco Steel [1999] CLC 647 at 651 (per Colman J).

${ }^{68}$ Renusagar Power Co. Ltd. v. General Electric Co., 1994 AIR 860.

${ }^{69}$ Oil \& Natural Gas Corporation Ltd. Vs. SAW Pipes Ltd, AIR 2003 SC 2629. The Court held that

It can be stated that the concept of public policy connotes some matter which concerns public good and the public interest. What is for public good or in public interest or what would be injurious or harmful to the public good or public interest has varied from time to time. However, the award which is, on the face of it, patently in violation of statutory provisions cannot be said award be in public interest. Such award/judgment/decision is likely to adversely affect the administration of justice.

70 The Renusagar case was concerned with the interpretation of public policy in the context of enforcement of an award whilst the Saw Pipes / the ONGC case was with the validity of the arbitral award under challenge. See generally, Garima Budhiraja Arya and Tania Sebastian, 'Critical Appraisal of Patent Illegality as a Ground for Setting Aside an Arbitral Award in India' (2012) 24 Bond L Rev 157; Shaneen Parikh, 'Setting Aside an Award on the Grounds of Arbitrability, Public Policy and Patent Illegality', in Dewan, supra note 42, at 99.

71 Oil \& Natural Gas Corporation Ltd. vs. SAW Pipes Ltd, AIR 2003 SC 2629.

72 Phulchand Exports Ltd. versus OOO Patriot, (2011) 10 SCC 300.

732011 (1) Arb L R 244 (Delhi): (2011) ILR 2 Del 181.

74 Oil \& Natural Gas Corporation Ltd. vs. SAW Pipes Ltd, AIR 2003 SC 2629.
} 
list of documents/statutes from which public policy principles can be gathered. Courts will also have to glean it from many other statutes meant to protect public interest, public morality and public security.

In Pakistan, the Courts have defined, rather broadly, public policy in the context of enforcement of foreign awards as follows:

[o]bjects which on grounds of public policy invalidate contracts may, for convenience, be generally classified into five groups. First, objects which are illegal by common law or by legislation; secondly, objects injurious to good Government either in the field of domestic or foreign affairs; thirdly, objects which interfere with the proper working of the machinery of justice; fourthly, objects injurious to family life; and fifthly, objects economically against the public interest. ${ }^{75}$

It is noticeable that as opposed to English law ${ }^{76}$ the notion of public policy in the laws of India (pre-2015 era as far as it relates to international arbitration), Pakistan and Bangladesh occasionally tends to have a wider scope as will be discussed below.

\section{Public Policy in the Indian Subcontinent}

First document containing provisions for arbitration in the colonial British India was the Bengal Regulation of $1772 .{ }^{77}$ In the year 1899, Indian Arbitration Act 1899, modelled on the English Arbitration Act 1899 was enacted. It was applied only to the Presidency towns of Bombay, Calcutta and Madras. Later in the year 1908, provisions related to arbitration was introduced in the Code of Civil Procedure. ${ }^{78}$ The consolidation of both, Indian Arbitration Act 1899 and provision related to arbitration in the Code of Civil Procedure, resulted in a new enactment with the title of the Arbitration Act 1940. In order to give effect to the Geneva Protocol on Arbitration Clauses of 1923 and the Geneva Convention on the Execution of Foreign Awards of 1927, an enactment with the short title 'the Arbitration (Protocol and Convention) Act 1937' was enacted. Thus, after partition both India and Pakistan inherited from the colonial master, through adaptation, these two legislations, i.e., The Arbitration Act 1940 and The Arbitration (Protocol and Convention) Act 1937.

Section 30 of the Arbitration Act 1940 provided grounds for the setting aside of an award, which includes inter alia when an award is 'otherwise invalid' - a very wider scope for the setting aside of an award. ${ }^{79}$ Section 7 of the Act 1937 required in subsection (e) a precondition for enforcement of a foreign arbitral award that its enforcement must not be contrary to public policy of that country.

\footnotetext{
75 Nan Fung Textiles Ltd. v. Sadig Traders Ltd. (High Court, Karachi) PLD 1982, 619.

76 See IBA, supra note 46.

77 Ben Steinbruck, International Commercial Arbitration - A Handbook (Munich: Beck, Hart, Nomos, 2015), p. 448.

78 Ibid.

79 Section 30 reads
}

Ground for setting aside award - An award shall not be set aside except on the one or more of the following grounds, namely (a) that an arbitrator or umpire has misconducted himself or the proceedings; (b) that an award has been made after the issue of an order by the Court superseding the arbitration or after arbitration proceedings have become invalid under section 35; (c) that award has been improperly procured or is otherwise invalid. 


\subsection{Public policy of India}

As stated above, after independence India inherited from the colonial master, through adaptation, ${ }^{80}$ two legislations, i.e., The Arbitration Act 1940 and The Arbitration (Protocol and Convention) Act 1937. On 13 July 1960 India ratified the Convention on the Recognition and Enforcement of Foreign Arbitral Awards 1958, therefore, in order to give it effect enacted 'the Foreign Awards (Recognition and Enforcement) Act 1961 whereby the Arbitration (Protocol and Convention) Act 1937 was also repealed. In August 1996 Indian Parliament enacted the Arbitration and Conciliation Act 1996 - an enactment consolidating both the domestic and international arbitration. It is modelled upon UNCITRAL Model Law, containing some historical reflections of English law and practices. ${ }^{81}$ It repeals both the Arbitration Act 1940 and the Foreign Awards (Recognition and Enforcement) Act 1961. Further, India is not a party to the ICSID Convention; however, it has entered into many bilateral investment treaties which provide for arbitration for resolution of investment dispute.

Arbitration and Conciliation Act 1996 consists of two parts, part 1 whereof deals with domestic arbitration, and part II provides mechanism for the recognition and enforcement of foreign arbitral awards. Its section 34(2) (b) (ii), falling in part I, applicable to domestic arbitral award, states in relation to public policy:

An arbitral award may be set aside by the court only if - the Court finds that - the arbitral award is in conflict with the public policy of India.

Explanation: Without prejudice to the generality of sub-clause (ii), it is hereby declared, for the avoidance of any doubt, that an award is in conflict with the public policy of India if the making of the award was induced or affected by fraud or corruption or was in violation of section 75 or section 81 .

Section 48 (2) (b), falling in part II, dealing with enforcement of foreign arbitral award, states in relation to public policy:

Enforcement of an arbitral award may also be refused if the Court finds that -

a. the subject-matter of the difference is not capable of settlement by arbitration under the law of India; or

b. the enforcement of the award would be contrary to the public policy of India.

Explanation: Without prejudice to the generality of clause (b), it is hereby declared, for the avoidance of any doubt, that an award is in conflict with the public policy of India if the making of the award was induced or affected by fraud or corruption.

The concept of public policy was tested in Renusagar Power Co. Ltd v General Electric Co. ${ }^{82}$ wherein the Indian Supreme Court defined the concept found in the Foreign Awards (Recognition and Enforcement) Act 1961 in the following words:

\footnotetext{
${ }^{80}$ Indian Independence (Adoption of Central Acts and Ordinance) Order 1948.

${ }^{81}$ S.R. Garimella, 'Issues of Jurisdiction, Choice of Law and Enforcement in International Commercial Arbitration: An Indian Perspective', in Sai Ramani Garimella and Stellina Jolly (eds.), Private International Law: South Asian Sates' Practice (Springer, 2017), p. 323.

82 AIR 1994 SC 860.
} 
Since the Foreign Awards Act is concerned with recognition and enforcement of foreign awards which are governed by the principles of private international law, the expression 'public policy' in S. 7(1)(b)(ii) of the Foreign Awards Act must necessarily be construed in the sense the doctrine of public policy is applied in the field of private international law. Applying the said criteria it must be held that the enforcement of a foreign award would be refused on the ground that it is contrary to public policy if such enforcement would be contrary to (i) fundamental policy of Indian law; or (ii) the interests of India; or (iii) justice or morality.

In $O N G C \quad v S P L,{ }^{83}$ a matter relating to domestic award, under Arbitration and Conciliation Act 1996, examined the definition of public policy expounded in the Renusagar case and assigned a dynamic and wider approach to it by holding that the 'concept connotes the public good and public interest' which continue to vary 'from time to time'. It held an award being 'patently in violation of statutory provisions' and adversely affecting administration of justice as 'patently illegal'. ${ }^{84}$ Further, the ONGC case not only added one head, i.e., patent illegality, to already three heads of public policy given in the Renusagar case but also obliterated the distinction, in relation to application of concept of public policy, between domestic and foreign award and between part I and part II of the Arbitration and Conciliation Act $1996 .{ }^{85}$

Similarly, in Bhatia International v Bulk Trading S.A, ${ }^{86}$ the Supreme Court held that provisions of part I of the Arbitration and Conciliation Act 1996 will apply to international arbitration held outside of India except where its application is specifically excluded by the parties. ${ }^{87}$ In line with it, in another case, Venture Global Engineering v. Satyam Computer Service, ${ }^{88}$ the Supreme Court held that a foreign award can be challenged under section 34 of the Arbitration and Conciliation Act 1996, a section which provides grounds for challenge of domestic arbitral award. In the same tune, Indian Supreme Court further held in Phulchand Export Ltd v OOO Patriot case that a foreign award can, in view of the ONGC case, be set aside if found 'patently illegal' - fourth head of public policy invented in the ONGC case pertaining to domestic arbitral award. ${ }^{89}$

Later on, in 2012, in Bharat Aluminium Co. v Kaiser Aluminium Technical Service Inc. the Indian Supreme Court overruled both the judgments rendered in Bhatia case and Venture

\footnotetext{
83 Oil \& Natural Gas Corporation Ltd v SAW Pipes Ltd, AIR 2003 SC 2629.

${ }^{84}$ Oil \& Natural Gas Corporation Ltd v SAW Pipes Ltd, AIR 2003 SC 2629 the Court held, 'in our view, the phrase "Public Policy of India" used in S. 34 in context is required to be given a wider meaning. It can be stated that the concept of public policy connotes some matter which concerns public good and the public interest. What is for public good or public interest has varied from time to time.'

${ }^{85}$ See generally, Badrinath Srinivasan, 'Public Policy and Setting Aside Patently Illegal Arbitral Awards in India' (March 27, 2008). Available at SSRN: https://ssrn.com/abstract=1958201 or http://dx.doi.org/10.2139/ssrn.1958201 (accessed September 2019).

862004 (2) SCC 105.

87 See the commentary, R. Sharma, 'Bhatia International v Bulk Trading S.A.: Ambushing International Commercial Arbitration outside India?’ Journal of International Arbitration, 2009, 26(3): 357.

${ }^{88} 2008$ (4) SCC190. See for a commentary by F. Nariman, 'India and International Arbitration', The George Washington International Law Review, 2010, 41: 367.

${ }^{89}$ See the commentaries on Oil \& Natural Gas Corporatgion v. Saw Pipes - S. Kachwaha, 'Enforcement of Arbitration Awards in India', Asian International Arbitration Journal, 2008, 4: 65; J. Gaya, 'Judicial Ambush of Arbitration in India', Law Quarterly Review, 2004, 571; N. Dewan, 'Arbitration in India: An Unenjoyable Litigating Jamboree!', Asian International Arbitration Journal, 2007, 3(1): 99; Anton G. Maurer, The Public Policy Exception under the New York Convention (JurisNet, LLC, New York, 2013), at 231-317.
} 
Global Engineering case. It held that Part I of Arbitration and Conciliation Act 1996 has no application to international arbitration held outside of Indian, therefore, such foreign award can only be subject to jurisdiction of the Indian courts when enforcement is sought under part II. In the same tune, the Supreme Court in Shri Lal Mahal Ltd v Progetto Grano Spa case (2013 $)^{90}$ held that the expanded and wider definition of public policy expounded in the ONGC case cannot be applied to foreign arbitral awards and further that the expression 'public policy of India' provided in section 48(2)(b) of the Act should be given narrow meaning as given in the Renusagar case. In this case again the Supreme Court has given, what is termed by S.R. Garimella, 'different threshold' for domestic arbitration and international arbitration ${ }^{91}$ and set precedent for the Indian court not to review a foreign award on the ground of 'patent illegality'. ${ }^{92}$

Again in ONGC $v$ Western Geco ${ }^{93}$ and Associate Builder $v$ DDA the Supreme Court has adopted a very wider scope of public policy. This leads to criticism of the Law Commission of India which stated that $O N G C v S P L^{94}$ had opened 'the floodgates' and $O N G C v$ Western Geco ${ }^{95}$ and Associate Builder $v D D A^{96}$ had reinforced the broad scope of public policy. ${ }^{97}$ In 2015, all this culminated into amendment in sections 34 and 48 Arbitration and Conciliation Act 1996 whereby the concept of public policy has been explained differently for domestic and foreign arbitration. The amended section 34, which deals with domestic award, does contain broad scope of public policy since it includes 'patent illegality' as additional head of public policy. ${ }^{98}$ On the other hand, patent illegality is missing in the explanation of public policy provided under the amended section 48 . Now section 48 explains that an award is in conflict of public policy of India if-

a. making of the award was induced or affected by fraud or corruption; or in the violation of the provision of confidentiality or admissibility of evidence of conciliation proceeding;

b. award is in violation of fundamental policy of Indian law, however, such test shall not entail a review on the merits of the dispute; or

\footnotetext{
90 Available at: https://indiankanoon.org/doc/15591279/ (accessed September 2019).

91 Garimella, supra note 81.

92 Sameer Sattar, 'Enforcement of Foreign Arbitral Awards in Bangladesh: The Law, Its Implementation and Challenges' in Garimella and Jolly, supra note 81, at 303.

93 (2014) 9 SCC 263.

94 Oil \& Natural Gas Corporation Ltd v SAW Pipes Ltd, AIR 2003 SC 2629.

95 (2014) 9 SCC 263.

96 Available at: https://indiankanoon.org/doc/31621011/ (accessed September 2019).

97 Available at: http://Lawcommissionofindia.nic.in/reports/supplementary (accessed September 2019). See also 'Public Policy in Indian Arbitration' (Ashurst, 1 March 2015), available at: https://www.ashurst.com/en/news-andinsights/legal-updates/public-policy-in-indian-arbitration/ (accessed September 2019).

98 The Arbitration and Conciliation (Amendment) Act 2015 (No.3 2016) [31 ${ }^{\text {st }}$ December 2015):
} Section 34(2A)

An arbitral award arising out of arbitrations other than international commercial arbitrations, may also be set aside by the Court, if the Court finds that the award is vitiated by patent illegality appearing on the face of the award:

Provided that an award shall not be set aside merely on the ground of an erroneous application of the law or by re-appreciation of evidence.

Available at https://upload.indiacode.nic.in/showfile?actid=AC_CEN_3_46_00004_199626_1517807323919\&typ e=statute \&filename=arbi\%20amend\%202015.pdf (accessed September 2019). 
c. award is in conflict with the most basic notions of morality or justice. ${ }^{99}$

In Cruz City 1 Mauritius Holding v Unitech Limited, ${ }^{100}$ in a proceeding for enforcement of an award, the concept of public policy after the 2015 amendment was tested. The respondent tried to resist enforcement on the ground of violation of public policy of India because award as well as the agreement allegedly violated some provisions of the Foreign Exchange Management Act, 1999. The High Court of Delhi at New Delhi seeking guidance from the dictum, 'contravention of law alone will not attract the bar of public policy', as enunciated in the Renusagar case, held that contravention of a provision of law alone is not enough for invoking the violation of public policy because these both are not synonymous. Rather, for 'fundamental policy of India' any 'particular provision of a statute' did not satisfy narrow scope of public policy, rather fundamental public policy connotes 'principles and the legislative policy on which Indian Statutes and laws are founded' meaning thereby, 'the basic and substratal rational, value and principles which form the bedrock of laws' in India. The judgement further held that 'the court was not precluded from examining the question of public policy suo motu.' The Court interpreted public policy concept of India after the 2015 amendment in section 48 in the following words:

(T)he explanation to section 48(2)(b) of the Act as amended / introduced by the Arbitration and Conciliation (Amendment) Act, 2015 have brought about a material change and further narrowed the scope of the public policy defence: first, Explanation 1 has sought to replace the inclusive scope of the pre-amendment provision by an exhaustive one; second, interest of India is no longer included in the scope of public policy; and third, it has been expressly provided - although the same was authoritatively settled by the Supreme Court in Resusagar Power Co. Ltd. v. General Electric Co.-that examination of whether the arbitral award offends the Fundamental Policy of Indian law, does not entail a review on merits.

Again, in Venture Global Engg. v. Satyam Computer Service Ltd, ${ }^{101}$ Justice Sapre of Supreme Court relying on Associate Builder's case endorsed the decision of the Trial Court whereby a foreign award (LCIA-Award) was set aside on the ground that direction contained in the award for transfer of share at book-value violated the provisions of Foreign Exchange Management Act 1999. He found violation of provision of the Act 1999 as amounted to patent illegality, thus, violation of public policy. Again 'patent illegality' reincarnated as a ground for the setting aside of a foreign award, or in other words, a foreign award can be set aside under section 34 of the 1996 Act - a section which specifically deals with domestic arbitration or award. Whereas, Justice Chelaeswar, another judge of the same division Bench, dissented with Justice Sapre and criticised the decision of the Trial Court on the ground that theTrail Court did not identify the provision of the Act 1999 which specifically was violated by the award. Further, Justice Chelaseswar found that the theory of causative link between the concealment of facts and the making of the award has not been proved with cogent reasons, therefore the award was

\footnotetext{
${ }^{99}$ Explanation to Section 48 (2) of Arbitration and Conciliation Act 1996 after amendment. 1002017239 DLT 649.

101 (2018) 1 SCC 656.
} 
not opposed to public policy. Consequently, the matter has been referred to the larger Bench of the Supreme Court of India. Though this matter was earlier remanded by the Supreme Court and pertained to events occurred before the amendment of 2015, therefore, until the decision of larger Bench of the Supreme Court is rendered it can easily be assumed that concept of public policy of India after the 2015 amendment in relation to enforcement of foreign arbitral award may be said to be based upon interpretation laid down by the High Court of Delhi in Cruz City 1 Mauritius Holding v Unitech Limited ${ }^{102}$ which is

i. The Court can examine question of public policy suo motu;

ii. Violation of any provision of law is not synonymous to violation of public policy;

iii. Fundamental public policy of India connotes basic, substratal values and principles foundational to legislative policy on which Indian Statutes and laws are founded.

Indian public policy on arbitrability is reflected in Booz Allen and Hamilton Inc. v. SBI Home Finance Ltd. ${ }^{103}$ The Supreme Court has applied a test based on rights in rem and right in personam. Matters involving rights in personam are declared to be arbitrable and matters involving rights in rem are not. ${ }^{104}$ The former are those rights which are connected with particular person while the later are those rights which relates to the world at large. Following the test, the court found, the following matters beyond the scope of arbitration, i.e., criminal offences; matrimonial disputes; guardianship; insolvency and winding up; and tenancy governed by a special statute because these involve rights in rem. However, the court cautioned that this right-based analyses in not inflexible because, sometime, subordinate rights from matters involving in rem might be arbitrable, e.g., rights under a patent licence agreement can be arbitrable, but the validity of the patent may not be. ${ }^{105}$

\subsection{Public Policy of Pakistan}

As stated earlier, Pakistan too after attaining independence, following the partition of British India, inherited laws including contract Act 1872, Arbitration Act 1940 and the Arbitration (Protocol and Convention) Act 1937 from the colonial master and adopted them vide the Adoption of Central Acts and Ordinances Order, 1949. The Arbitration Act 1940 provides a regime for domestic arbitration. The Arbitration (Protocol and Convention) Act 1937 provided legal mechanism for enforcement of foreign arbitral agreements and awards. In 2005, Pakistan enforced the Recognition and Enforcement (Arbitration Agreements and Foreign Arbitral Awards) Ordinance 2005 which was promulgated pursuant to the ratification of the New York Convention to which it has been a signatory since 1958. Thus, it applied the New York Convention for the first time in 2005 and till then the Act of 1937 remained the law of the land

\footnotetext{
1022017 239DLT 649. See also Shri Vimal Kishor Shah and Ors v Mr. Jayesh Dinesh Shah and Ors. Civil Appeal no 8164 of 2016; A Ayyasamy v A Paramasivam \& Ors, Civil Appeal Nos 8245 \& 8246 of 2016.

103 AIR 2011 SC 2507. See also Vyapak Desai, M. Khan and P. Chatterjee, 'Public Policy and Arbitrability Challenges to the Enforcement of Foreign Awards in India', in Dewan, supra note 42, at 201; Shaneen Parikh, 'Setting Aside an Award on the Grounds of Arbitrability, Public Policy and Patent Illegality', in Dewan, supra note 42, at 99.

104 Ibid.

105 AIR 2011 SC 2507.
} 
on the subject. As the Ordinance could not take shape of the Act of Parliament; therefore after its lapse, ${ }^{106}$ in order to fulfil international obligations, another ordinance was promulgated in 2006. ${ }^{107}$ This Ordinance was repeated by successive ordinances, viz., the Recognition and Enforcement (Arbitration Agreements and Foreign Arbitral Awards) Ordinance $2007^{108}$ of $2009^{109}$ and of 2010. ${ }^{110}$ Ultimately, it took the shape of an Act of Parliament, namely, the Recognition and Enforcement (Arbitration Agreements and Foreign Arbitral Awards) Act, 2011(hereinafter referred as Act of 2011). Thus, now the foreign arbitral awards are enforced under the New York Convention through the Act of 2011. At present, Pakistan has two different pieces of legislation dealing with arbitration. The Arbitration Act 1940 deals with domestic arbitration and the Act of 2011 foreign arbitration. In order to consolidate these two pieces of legislation, a bill, modelled on the UNCITRAL Model Law, was introduced in the Senate of Pakistan in January $2016^{111}$ which has not yet seen the light of the day.

Section 23 of the Contract Act 1872 mandated the court to declare an agreement void when it considers it to be violative of law or any provision of law, fraudulent, injurious to the person or property of third person, immoral or opposed to public policy. Section 30 of the Arbitration Act 1940 sets out grounds for the setting aside of an award, i.e., misconduct of the arbitrator in the proceeding or improper procurement of award or invalidity of award. Section 7 of the Arbitration (Protocol and Convention) Act 1937 has provided a precondition for enforcement of a foreign arbitration award in the wordings that its enforcement 'must not be contrary to public policy or law of Pakistan'.

As stated above, the concept of public policy appears in various enactments but neither this term has been defined nor has its scope been determined in any legislation in Pakistan. Yet some discussions may be found in the decisions of the superior courts. In 1969, in the case of the Official Assignee of the High Court of West Pakistan v The Lloyds Bank Ltd. Karachi and others, ${ }^{12}$ the Supreme Court of Pakistan observed that when a protective right is claimed under the orbit of public policy the basic consideration, for the courts, is to avoid harm to the general public. The duty of the courts is to expound and not to expand the public policy, while the doctrine should be invoked only in clear cases, in which the harm to the public is substantially incontestable. ${ }^{113}$ In Sultan Textile Mills Ltd v Mohd. Yousuf Shamsi, ${ }^{114}$ the same principles were reiterated and the following two rules were laid down:

\footnotetext{
106 Under Article 89 of the Constitution of Pakistan, 1973 an Ordinance stands repealed at the expiration of one hundred and twenty days from the date of its promulgation. Therefore, after the lapse of this Ordinance successive Ordinances for the purpose of applying the New York Convention were continued to be promulgated.

107 Recognition and Enforcement (Arbitration Agreements and Foreign Arbitral Awards) Ordinance 2006 (Ordinance III of 2006) dated 18 March 2006 and published in Gazette of Pakistan, Extraordinary, Part I, 18 March 2006.

108 Ordinance XXV of 2007 published in Gazette of Pakistan, Extraordinary, Part I, 2 June 2007.

109 Ordinance XXXIII of 2009 published in Gazette of Pakistan, Extraordinary, Part I, 26 November 2009.

110 Ordinance IX of 2010 published in Gazette of Pakistan, Extraordinary, Part I, 20 April 2010.

111 www.senate.gov.pk/uploads/documents/1453277461_862.pdf (accessed September 2019).

112 PLD 1969 SC 301.

113 See Ijaz.A. Chishti, 'Issue of Jurisdiction, Choice of Law and Enforcement in International Commercial Arbitration: A Pakistan Perspective', in Garimella and Jolly, supra note 81, at 369.

114 PLD 1972 Karachi 226.
} 
a. It is not legitimate for a judge to invent a new head of public policy because a judge cannot speculate what is good for a community, rather, he has to apply already established rule, even on time, by moulding to fit the new conditions. Thus, he can expound and not expand the public policy.

b. The contract should be given benefit of doubt which means in case a contract falls under one of the recognised heads of public policy even then it will not be held illegal unless its harms to the community are indisputable.

In these cases, it emerged that the courts are in favour of fostering the contractual freedom of the parties but subject to prohibition where relationships are contrary to the general policy of law, injurious to and against the public good, contra bonos mores or that has arisen ex turip causa. ${ }^{115}$ These principles termed as fundamentals in laying down public policy - a term which otherwise is considered as a very imprecise and varying concept, in a sense, anathema to one generation may be harmless to another. ${ }^{116}$

In Wapada v Kot Addu Power Co. Ltd, ${ }^{117}$ the court defines public policy as a principle for protection and promotion of public welfare whereunder the freedom of contract or private dealing is restricted by law for the good of the community. Thus, it protects interest of the persons other than parties.

In Sardar Muhammad Yasin Khan v Raja Feroz Khan, ${ }^{118}$ the court examined a contract between parties where a reference to arbitration and abandonment of criminal prosecution was stipulated. An agreement, the court observed, which tends to prevent the course of justice or contradictory to the basic concept of administration of justice, i.e., ubi jus ibi remedium (for every wrong, the law provides a remedy) is opposed to public policy and void. But the aforesaid agreement does not deprive the aggrieved person of seeking remedy for the wrong done but only debars him from resorting to criminal prosecution, therefore it is not against the public policy. However, the court limited the application of such agreement to compoundable offences only. ${ }^{119}$

In Nan Fung Textiles Ltd. $v$ Sadiq Traders Ltd, ${ }^{120}$ the High Court of Sindh, while examining the challenge to a foreign award on the ground of public policy, seeking guidance from a case reported as AIR 1947 Sindh 94 (and Chitty on Contract), laid down a test based on the following grounds:

i. Trading with enemy in time of war;

\footnotetext{
115 PLD 1972 Karachi 226.

116 Ibid.

117 PLD 2000 Lahore 461

118 PLD 1972 AJ \& K 46.

119 Ibid. The Court defines the public policy as follows:
}

Public policy, therefore, means any act the allowing of which would be against the general interests of the community. This policy has involved itself with the growth of organised society. Certain standards in the domain of morality, used in widest sense, have assumed sanctity on account of the acceptance by the general community. Therefore, any agreement which would destroy these standards or adversely affect the development of society or its organisation have to be viewed from this angle and it is here the principle of public policy is born.

120 PLD 1982 Karachi 619. 
ii. Objects which are illegal by common law or by legislation;

iii. Objects injurious to good government either in the field of domestic affairs or foreign affairs;

iv. Objects which interfere with the proper working of the machinery of justice; such as, stifling with prosecution, champerty and maintenance;

v. Object injurious to family life;

vi. Object economically against the public interest.

In the Nan Fung Textiles Ltd. case, ${ }^{121}$ the application of the provisions of the Arbitration Act 1940 was discussed and held that the provisions of the Arbitration Act 1940 did not apply to the proceedings for enforcement of a foreign arbitral award under the provision of the Arbitration (Protocol and Convention) Act 1937. Therefore, the requirement under section 26A of the Arbitration Act 1940 - that a domestic award must state reasons - cannot be treated as violation of public policy by a foreign award seeking enforcement. ${ }^{122}$

The above are conceivable heads of public policy, the judgment reads, but no exhaustive scope of public policy could be drawn because the rules governing public policy cannot remain immutable rather change with the passage of time.

In Inayat Ali Shah v Anwar Hussain, ${ }^{123}$ the legality of an agreement, whereby one party agreed to finance prosecution of two suits for pre-emption (superior right to buy immoveable property) and the other party agreed to share the gain of the suits, was examined on the touchstone of public policy. The Lahore High Court held that the agreement was against the public policy on the ground that right to pre-empt sale is a special right granted by the Punjab Pre-emption Act 1913 and by agreeing to share the gains in a suit for pre-emption with others would clearly amount to set at nought the provisions [rather the underlying purpose] of the Act.

In Grosvenor Casino Ltd v Abdul Malik Badruddin, ${ }^{124}$ a matter for enforcement of a foreign decree under section 44-A of the Code of Civil Procedure (CPC) 1908 came up for hearing before a judge of the High Court of Sindh, namely, Mr. Justice Rana Bhagwan Das. The issue that involved a ground for resisting enforcement of a foreign decree was to consider whether the decree for recovering gambling debt cannot be enforced in Pakistan by reason of section 13 (f) of the Code of Civil Procedure 1908 which provides for exception to the enforcement of a foreign decree when it sustains on a claim founded on a breach of any law in force in Pakistan. The judgement held that the act of gaming and gambling is not only prohibited by the Gambling Ordinance 1961 but also repugnant to injunctions of the Qur'an and the Sunnah which are embedded in every statute and every statute being repugnant to such injunction would be void. The principle laid down in this judgement is, in fact, based on the constitutional mandate provided in Article 227 of the Constitution ${ }^{125}$ which renders void any

\footnotetext{
121 PLD 1982 Karachi 619.

122 PLD 1982 Karachi 619.

1231995 CLC 1906.

124 Grosvenor Casine Ltd. v. Abdul Malik Badruddin, PLD 1998 Karachi 104.

125 Article 227 of the Constitution 1973 reads 'all existing laws shall be brought in conformity with the Injunctions of Islam as laid down in the Holy Qur'an and Sunnah ... and no law shall be enacted which is repugnant to such Injunctions.'
} 
law found repugnant to the injunctions of the Qur'an and the Sunnah and, as elaborated by two precedents of the full Bench of the Federal Shariat Court, one, in Raja Khushbakht ur Rehman $v$ The Province of Pubjab's case ${ }^{126}$ whereby betting on horses being gambling declared against the injunctions, and second, in Mushtaq Ali v Government of Pakistan ${ }^{127}$ whereby lottery scheme was declared against the injunctions of Islam. Thus, execution was failed on the ground of its being violative of the public policy contemplated in section 30 of the Contract Act, section 13 (f) of the CPC and the prohibition contained in the injunctions of the Qur'an and the Sunnah. ${ }^{128}$

A judgment of the Federal Shariat Court in 1991 declared Riba (Interest) 'in all its forms and manifestations' repugnant to the Injunction of Islam and consequently the Interest Act 1839 was directed to be repealed. This judgment was also affirmed by the Supreme Court of Pakistan in 1999. ${ }^{129}$ But, later on, the Supreme Court reviewed its own very affirming judgment in 2002, set aside its own judgement as well as the 1991 judgment of the Federal Shariat Court and remanded the case back to the Federal Shariat Court for reconsideration. ${ }^{130}$

Currently, in Pakistan, the Interest Act 1839 is valid law of the country. Hence, interest is not unlawful and it is also permissible for enforcement court to impose interest in addition to award under section 29 of the Arbitration Act 1940. ${ }^{131}$ Sometime courts wrongly hold that award with interest cannot be enforced. ${ }^{132}$ However, it may be declared unlawful by the Federal Shariat Court of Pakistan where the matter is still pending.

The principles of law of any country also set parameters of public policy of that country. Laws are true reflection of public policy of a country. ${ }^{133}$ Such laws include contract law, competition law, human rights law and environmental law, etc. In the case of Jivraj v. Hashwani the British Supreme Court has declared the arbitration agreement as a whole as void because it

126 PLD 1986 FSC 49.

127 PLD 1989 FSC 60. The same judgement was also upheld by the Shariat Appellate Bench of the Supreme Court in Federation of Pakistan v. Mushtaq Ali, PLD 1992 SC 153.

128 Grosvenor Casine Ltd. v. Abdul Malik Badruddin, PLD 1998 Karachi 104.

129 Dr. M. Aslam Khaki v Syed M. Hashim, PLD 2000 SC 225.

130 United Bank Ltd. v. M/s Farooq Brothers, PLD 2002 Supreme Court 801.

131 Section 29 of the Arbitration Act, 1940 reads:

Interest on award - Where and insofar as an award is for the payment of money the Court may in the decree order interest, from the date of the decree at such rate as the Court deems reasonable, to be paid on the principal sum as adjudged by the award and confirmed by the decree.

1322006 CLD 697, Messers Flame Maritime Limited v Messers Hassan Ali Rice Export. This case is wrongly decided by the High Court. In this case it was one of the objections to the enforcement of foreign arbitral award in Pakistan that the arbitrator awarded interest which is against the Shariah, therefore it cannot be enforced in Pakistan in view of the above referred judgment of the Supreme Court (2000), whereupon, the single Judge of the High Court of Sindh wrongly relied on the precedent laid in the 1999 judgment (despite its being set aside by the 2002 review judgment of the same Supreme Court) and held that in view of the Supreme Court judgment 'the enforcement of interest in Pakistan is repugnant to the injunction of Islam, therefore, the enforcement of interest as awarded would be against the law prevalent in Pakistan'. Nonetheless, the award was made rule of the Court excluding the interest. 133 Christ for all Nations v. Appolo Insurance Co. Ltd., [1999] LLR. 1635, the similar terms in Christ for all Nations v. Appolo Insurance Co. Ltd. the High Court of Kenya have held that the notion of Kenyan public policy covers that award which is inconsistent with the laws of Kenya; Oberlandesgericht Dresden, Germany, 11 Sch 01/05, 2 April 2005, available at www.dis-arb.de/de/47/datebanken/rspr/olg-dresdem-az-11-sch-01-05-datum-2005-04-id307 (accessed September 2019), wherein it is held that as in a case a court in Germany has held that prohibitions of competition law express a country's resolve to a free market and compliance with such prohibitions is of fundamental importance for that country therefore a competition law is a part of public policy of the country; Also Ghodoosi quotes argument of Reisman in Ghodoosi, 2017, supra note 2, at 25. 
has one of the requirements that arbitrator shall be from the Ismaelli community which contravened the Employment Equality (Religion and Belief) Regulation 2003. ${ }^{134}$ The English Court has held in another case, i.e., Sion Soleimany v. Abner Soleimony, that:

An English Court will not enforce a contract governed by English Law, or to be performed in England, which is illegal by English domestic law. Nor will it enforce a contract governed by the law of a foreign and friendly state, or which requires performance in such a country, if performance is illegal by the law of that country..... This rule applies as much to the enforcement of an arbitration award as to the direct enforcement of a contract in legal proceedings. ${ }^{135}$

In Pakistan, it has been held in Grosvenor Casino Ltd. that section 30 of the Contract Act stipulates that any agreement by way of wager is void. Therefore, no suit can succeed for recovering anything alleged to be won on any wager being violative of principle of public policy. ${ }^{136}$ In order to refuse enforcement the court is required to see whether the alleged requirement of law is mandatory or mere directory. Only mandatory requirements of law can be termed as policy of law. In the Manzoor Hussain case, ${ }^{137}$ the court has rejected the argument requesting it to declare a contract as having defeated the provisions of the Foreign Exchange Regulation Act, therefore opposed to public policy. The Supreme Court finds that the Foreign Exchange Regulation Act does not forbid the making of a contract which may contemplate doing a thing which is contrary to the provisions of the Foreign Exchange Regulations Act, if such things can be done by ex post facto permission of the State Bank of Pakistan. The court has upheld the concept that court should construe strictly the provisions of section 23 of the Contract Act and not to invent new categories or new heads of public policy. ${ }^{138}$ In the case of Nan Fung Textiles Limited versus Sadiq Traders Limited it has been held in regard to foreign award that any non-compliance with the provisions of the Arbitration Act 1940 cannot be termed as against the public policy of Pakistan, nor will it invalidate a foreign award. ${ }^{139}$

It has been held in the Ali Muhammad case ${ }^{140}$ that when in terms of agreement between the parties to refer the matter to arbitrator, subject matter of criminal litigation is specifically mentioned and made the subject matter of arbitration and the award also indicates the settlement of dispute including the withdrawal of the criminal cases as part of settlement between the parties, on these facts, the matter of the reference to the arbitrator as well as of the award, are opposed to public policy because they deal with criminal case for its prosecution or non-prosecution and the award directing the withdrawal of the criminal case or its nonprosecution by one of the parties. ${ }^{141}$ This decision though based on the decision in Gopal Chandra Poddar v. Lakshmi Kunta Sha ${ }^{142}$ wherein it was held that an agreement to refer to arbitration in consideration for dropping a criminal proceeding in respect of "non-

\footnotetext{
134 Jivraj v. Hashwani, 2010 EWCA Civ. 2003.

135 Sion Soleimany v. Abner Soleimony, YCA, XXIV (1999) p. 753; [1999] QB 785.

136 Grosvenor Casine Ltd. v. Abdul Malik Badruddin, PLD 1998 Karachi 104.

137 Manzoor Hussain v. Wali Muhammad, PLD 1965 SC 425.

138 ibid.

139 PLD 1982 Karachi 619.

140 Ali Muhammad and others v Bashir Ahmad through his legal heirs, 1991 SCMR 1928.

141 Ibid.

142 Gopal Chandra Poddar v. Lakshmi Kunta Sha, AIR 1933 Cal. 817.
} 
compoundable offence' is opposed to public policy. But this, i.e., the Ali Muhammad case, went a step further by declaring that 'criminal matters' cannot be subject-matter of arbitration. On the other hand, the reading of Small Claims and Minor Offences Court Ordinance, 2002 suggests that now the policy of Pakistan is that only non-compoundable matters are not beyond the scope of arbitration. And all compoundable offences can, at any stage of the proceedings, with the consent of the parties, be decided by resorting to amicable settlement procedure, including, arbitration. ${ }^{143}$ However, an arbitrator, under this Ordinance is called Salis, ${ }^{144}$ which is a translation of the word 'arbitrator' in Urdu. The same is the policy under the Local Laws. For example, under the Punjab Local Government even the criminal compoundable matters can be referred for amicable settlement to Panchayat or Musalihat Anjuman, ${ }^{145}$ which in all practical purposes works as a penal of arbitrators

However, it is held in the Manzoor Hussain case ${ }^{146}$ that it is equally accepted rule that where a person invoking the aid of a court to invalidate a contract on the ground of illegality is himself implicated in the illegality, the court will not, as a rule, assist him and where a person has not raised the question of illegality before the arbitral tribunal, but raised after having found that the award has gone against him, then neither the law nor equity supports him.

\subsection{Public Policy of Bangladesh}

As stated earlier, after attaining independence, following the partition of British India, Pakistan inherited laws including the Contract Act 1872, the Arbitration Act 1940 and the Arbitration (Protocol and Convention) Act 1937 from the colonial master and adopted them vide the Adoption of Central Acts and Ordinances Order, 1949. The Arbitration Act 1940 provides a regime for domestic arbitration. The Arbitration (Protocol and Convention) Act 1937 provided legal mechanism for enforcement of foreign arbitral agreements and awards. Similarly, Bangladesh (former East Pakistan) inherited these laws of colonial legacy from Pakistan upon separating itself from Pakistan and attaining independence in 1971. In order to remove uncertainty associated with enforcement rules on foreign arbitral award, ${ }^{147}$ to fulfil international commitment under the New York Convention $1958^{148}$ and to consolidate both domestic and international arbitration, Bangladesh enacted the Arbitration Act 2001. ${ }^{149}$ This law though tainted with some unique features of the Indian Arbitration and Conciliation Act 1996 and the English Arbitration Act 1996 is generally modelled upon UNCITRAL Model Law. ${ }^{150}$ Chapter X of the Arbitration Act 2001 gives force to the New York Convention in the territory of Bangladesh.

\footnotetext{
143 Section 14 of Small Claims and Minor Offences Courts Ordinance, 2002.

144 Ibid., Section 2 (g).

145 Section 96 and 97 of the Punjab Local Government Act, 2013.

146 Manzoor Hussain v. Wali Muhammad, PLD 1965 SC 425.

147 See Bangladesh Air Service (Pvt) Ltd. v. British Airways PLC, 49 DLR (AD) (1997) 187; Haji Azam v. Singleton Binda end Co. Ltd, 27 DLR 583.

148 Bangladesh became a signatory to the New York Convention in 1992.

149 See generally, A F M Maniruzzaman, 'The New Law of International Commercial Arbitration in Bangladesh: A Comparative Perspective', American Review of International Arbitration, 2003, 14: 139.

150 Ibid.
} 
One commentator ${ }^{151}$ states that public policy to be followed in Bangladesh may be referred with respect to the restrictions, inter alia, given in the Contract Act 1872, which declares certain agreements as void in which part of consideration or object is unlawful, agreements is made without consideration, agreements made in restraint of marriage, uncertain agreements, wagering agreements, agreements contingent, impossible events or agreements to do impossible acts, etc. ${ }^{152}$

In Tata Power Company Ltd v M/S Dynamic Construction ${ }^{153}$ the Appellate Division of the Supreme Court of Bangladesh has discussed the concept of public policy and defined it as consisting of those "principles and standards regarded by the legislature or by the courts as being of fundamental concern to the state and the whole of society. ${ }^{154}$ A decision of the arbitrator, the judgement reads, is also in conflict with public policy which created negative impact on foreign companies making investment in Bangladesh.

The judgement differentiated between the matters relating to public policy and propriety. A mere illegality amounts to propriety whereas gross illegality is tantamount to conflict with public policy. A decision contrary to law, the law of the country is not in conflict with public policy unless there is gross illegality. ${ }^{155}$ One can perhaps equate the expression 'gross illegality' in the instant case with the expression 'patent illegality' as pronounced by the Supreme Court of India in $O N G C v S P L$ as discussed earlier. ${ }^{156}$ It is not clear, however, from the judgement of the Supreme Court of Bangladesh in the Tata Power Company Ltd. case whether any distinction should be made between a domestic award and a foreign award or a Bangladesh-seated nondomestic award while considering the ground of gross illegality.

\footnotetext{
${ }^{151}$ M. Hossain, 'Party Autonomy in the International Commercial Arbitration: Critical Evaluation of its Ambits and Limits' (2017) ALSA Academic Journal, AJLS, 60-75.

152 See section 25-30, 36 and 56 of the Contract Act 1872.

153 [2015] 2 SCOB 15 (AD), available at: www.lawyersnjurists.com/lawyer_ci/case/tata-power-company-ltd-vsms-dynamic-construction-4-lnj-ad-2015-317 (accessed September 2019).

154 This definition is taken from Black's Law Dictionary.

155 See also the Indian case Sikkim Subba Associates v. State of Sikkim (2001) 5 SSC 629, also available at: https://indiankanoon.org/doc/164262/ (accessed September 2019). The Indian Supreme Court noted the notion of 'gross illegality' in the award concerned in the following words:
}

The arbitrator who is obliged to apply law and adjudicate claims according to law, is found to have thrown to the winds all such basic and fundamental principles and chosen to award an astronomical sum as damages without any basis or concrete proof of such damages, as required in law.

Illegality must go to the root of the matter and if the illegality is of trivial nature it cannot be held that award is against the public policy. Award could also be set aside if it is so unfair and unreasonable that it shocks the conscience of the Court. Such award is opposed to public policy and is required to be adjudged void.

- Oil \& Natural Gas Corporation Ltd vs Saw Pipes Ltd on 17 April, 2003 (the Supreme Court of India), available at: https://indiankanoon.org/doc/919241/ (accessed September 2019). See also Mr.Syed Basheer Ahmed v. M/S. Cholamandalam Investments (25 April, 2019) (Madras High Court):

29. It is made clear that in the considered view of this Court patent illegality is something which is so obvious and so conspicuous on the face of the impugned award that no process of inference needs to be resorted to, to detect the same.

33.... with regard to patent illegality it is not a case of erroneous application of law and it is not a case warranting re-appreciation of evidence.

Available at: https://indiankanoon.org/doc/177583713/ (accessed September 2019). 
Matter relating to propriety includes when decision is contrary to law, the arbitrator has travelled beyond the terms of reference, misinterpreted a principle of law or precedent or misreading or non-reading of evidence. Finally, only those contracts and awards which have negative or uncalled-for impact either on state or society are treated in Bangladesh as contrary to public policy. ${ }^{157}$ From this decision it could be concluded that Bangladesh Supreme Court's approach to the scope of public policy is rather expansive. ${ }^{158}$

\subsection{Public Policy in the Indian Subcontinent - A Common History, the Same Concept but a Different Approach}

\subsubsection{A Common history}

As stated earlier, arbitration in British India was introduced through the Bengal Regulation of 1772. ${ }^{159}$ In 1899 Indian Arbitration Act, modelled on English Arbitration Act 1899 was enacted. In 1908, some provisions on arbitration in the Code of Civil Procedure 1908, the 1940 Arbitration Act and the 1927 the Arbitration (Protocol and Convention) Act 1937 was enacted. Thus, after partition all the countries of the subcontinent, i.e., India, Pakistan and Bangladesh inherited the same legacy. India, however, deviated from the rest in 1961 when it in order to give effect to the New York Convention 1958, enacted 'the Foreign Awards (Recognition and Enforcement) Act 1961 and repealed the application of Arbitration (Protocol and Convention) Act 1937. In August 1996, its Parliament enacted the Arbitration and Conciliation Act 1996an enactment consolidating both the domestic and international arbitration and in $2015^{160}$ and $2019^{161}$ two respective amendments to the 1996 Act were introduced. On the other hand, Pakistan took first step in 2005 when it gave effect to the New York Convention 1958 through legislation. It still has not consolidated laws dealing with domestic and international arbitration. Bangladesh, in 2001, has not only applied the New York Convention 1958 on its territory but has also consolidated both domestic and international arbitration by an enactment, namely, the Arbitration Act 2001.

\subsubsection{The same concept}

Despite having an identical legacy, the approach to public policy in the subcontinent is though not uniform but very closer to each other, which is evident in the following paragraphs:

(a) On the definition of public policy, there is larger uniformity in the approach of all the three countries of the Indian subcontinent. A contract or an award is considered contrary to public policy if their enforcement would be contrary to the fundamental policy of the law of the country

\footnotetext{
157 [2015] 2 SCOB 15 (AD), available at: www.lawyersnjurists.com/lawyer_ci/case/tata-power-company-ltd-vsms-dynamic-construction-4-lnj-ad-2015-317 (accessed September 2019).

${ }^{158}$ See Bangladesh Oil, Gas and Mineral Corporation ('Petrobangla') v. Saipem (H.C. Dev., Judgement, $21^{\text {st }}$ April 2004) 10 BLC 140. where the concept of public policy in Bangladesh was broadly conceived by including in it the notion of anything 'patently illegal'. $C f$. M. A. Khan, 'Issues of Jurisdiction, Choice of Law and Enforcement in International Commercial Arbitration: A Bangladesh Perspective', in Garimella and Jolly, supra note 81, at 285.

159 Ben Steinbruck, International Commercial Arbitration-A Handbook (Munich:Beck, Hart, Nomos, 2015),p 448.

160 The Arbitration and Conciliation (Amendment) Act 2015 (No.3 of 2016) (31 December 2015), available at: https://upload.indiacode.nic.in/showfile?actid=AC_CEN_3_46_00004_199626_1517807323919\&type=statute\&fil ename=arbi\%20amend\%202015.pdf (accessed September 2019).

161 The Arbitration and Conciliation (Amendment) Act, 2019 (No.33 of 2019) (9 August 2019), available at: http://egazette.nic.in/WriteReadData/2019/210414.pdf (accessed September 2019).
} 
or the interests of the country or justice or morality. ${ }^{162}$ The Indian Supreme Court in the matter of Booz Allen and Hamilton Inc. v. SBI Home Finance Ltd ${ }^{163}$ has applied the test of rights in rem whereby public policy comes into play for the protection of rights of non-contracting parties. Similarly, in Wapada v Kot Addu Power Co. Ltd ${ }^{164}$ the Lahore High Court stressed that the purpose of public policy is to protect the interest of the person other than the parties.

(b) With regard to Pakistan's approach, the Nan Fung Textiles Ltd. case, ${ }^{165}$ states that only conceivable heads of public policy can be given and no exhaustive scope of public policy could be drawn because the rules governing public policy cannot remain immutable rather change with the passage of time. Similarly, in India this concept is also considered as 'open-textured and flexible' which keeps changing and evolving with the passage of time. ${ }^{166}$

(c) Violation of public policy is not synonymous with the infringement of the provisions of any enactment. Rather, when the purpose and underlying cause of legislation is violated then such violation qualifies as violation public policy. The same approach is being uniformly followed in the Indian Subcontinent. ${ }^{167}$

(d) Every country is run through a social contract, the violation of whose mandates is considered to be a social degradation, if not anarchy. Therefore, every country protects it for the survival of its own, i.e., 'self-preservation'. The social contract of Pakistan is called 'Constitution of the Islamic Republic of Pakistan 1973', of Bangladesh is called 'Constitution of the People's Republic of Bangladesh' and of India is called 'Constitution of India'. So, the principles of each of the Constitutions truly depict the contours of public policy of the respective countries. India and Bangladesh have, through the interpretation of the Supreme Courts of the respective countries, established the doctrine of basic structure, in pursuance thereof, even the legislatures of the respective countries cannot amend the provisions which shape basic structure of the Constitution. ${ }^{168}$ Any law which contravenes the provisions of the Constitution cannot withstand. ${ }^{169}$ Fundamental rights have been specifically protected in the constitutions and any

162 Renusagar Power Co. Ltd. v. General Electric Co., 1994 AIR 860 and Explanation to Section 48 (2) of Arbitration and Conciliation Act 1996. In Nan Fung Textiles Ltd v Sadiq Traders Ltd, PLD 1982 Karachi 619, in order to ascertain the meaning of the public policy, placing reliance on the definition given in the book 'Chitty on Contract', different heads have been enumerated which all can be summarized into this definition. Further, concept of public policy provided in the contract Act of each country is verbatim identical.

163 AIR 2011 SC 2507.

164 PLD 2000 Lahore 461.

165 PLD 1982 Karachi 619.

166 Renusagar Power Co. Ltd. v. General Electric Co., 1994 AIR 860 and Central Inland Water Transport Corporation Ltd. v Brojo Nath, 1986 SCC 156.

167 In Renusagar Power Co. Ltd. v. General Electric Co., 1994 AIR 860, it was held that contravention of a provision of law alone is not enough for invoking the violation of public policy because both these are not synonymous. Rather, for 'fundamental policy of India' any 'particular provision of a statute' did not satisfy narrow scope of public policy, rather fundamental public policy connotes "principles and the legislative policy on which Indian Statutes and laws are founded" meaning thereby, "the basic and substratal rational, value and principles which form the bedrock of laws' in India. In Pakistan in Inayat Ali Shah v Anwar Hussain, 1995 CLC 1906, has found violation of the public policy when any act set at naught the [purpose] of the Act.

${ }_{168}$ In India the Supreme Court has laid down this doctrine in the case of Kesavananda Bharati v. State of Kerala (AIR 1973 SC 1641) and Indira Nehru Gandhi v. Shri Raj Narain (AIR 1975 SC 2299). In Bangladesh, this doctrine was followed in Anwar Hussain Chowdhury v. Government of the People's Republic of Bangladesh, 1989 BLD (Supplement) 1. Doctrine of basic structure was introduced by Professor Dietrich Conrad, a German professor of law.

169 Article of 7 of the Constitution of the People's Republic of Bangladesh reads: 
law, even made by the legislature, if it infringes fundamental rights, is void. ${ }^{170}$ Any award which is in violation of the Constitution is treated against the public policy of the country. ${ }^{171}$ The list of the 'Fundamental Rights' and the 'Directive Principles' enshrined in the Constitution are instrumental in shaping the public policy of the country. ${ }^{172}$ In the same tune, the German court has held that awards which infringe human rights are contrary to the public policy. ${ }^{173}$

\subsubsection{A different approach}

Pakistan is being run by the legal order, namely, the Constitution of the Islamic Republic of Pakistan 1973 (the Constitution). It begins with the preamble expounding that the sovereignty over the entire Universe belongs to Almighty Allah alone, and the authority and powers of the State is to be exercised by the people through chosen representative within the limits prescribed by the Almighty Allah. Therefore, certain limits, prohibitions of Shari'ah, have been put on the law-makers. Thus, the recognition and enforcement of a foreign award or judgement shall be refused in the case if recognition or enforcement would be in contradiction with the stipulations of Islamic law/Shari'ah. ${ }^{174}$ Mr. Justice Rana Bhagwandas, the then Judge of the High Court of Sindh (later on elevated as a judge of the Supreme Court) has held in the Grosvenor Casino $L t d .{ }^{175}$ case that when a foreign judgment ${ }^{176}$ sustains a claim prohibited by Shari'ah cannot be enforced in Pakistan. He further elaborates that the injunction of the Qur'an and the Sunnah are embedded in every statute and any statute being repugnant to such injunctions would be void. ${ }^{177}$ This principle is, in fact, based on the constitutional mandate provided in Article 227 of the Constitution which states, 'all existing laws shall be brought in conformity with the Injunctions of Islam as laid down in the Holy Qur' an and Sunnah ... and no law shall be enacted which is repugnant to such Injunctions.' However, any law which has not specifically been declared contrary to the injunction of Islam by the Federal Shariat Court cannot be said to be contrary to public policy even though the same is repugnant to the injunctions of the Qur'an and the Sunnah,

Supremacy of the Constitution. (1) All powers in the Republic belong to the people, and their exercise on behalf of the people shall be effected only under, and by the authority of, this Constitution. (2) This Constitution is, as the solemn expression of the will of the people, the supreme law of the Republic, and if any other law is inconsistent with this Constitution and other law shall, to the extent of the inconsistency, be void.

170 Article 8 of the Constitution of Pakistan, which reads:

(1) Any law, or any custom or usage having he force of law, in so far as is inconsistent with the rights conferred by this Chapter, shall, to the extent of such inconsistency, be void; (2) The State shall not make any law which takes away or abridges the rights so conferred and any law made in contravention of this clause shall, to the extent of such contravention, be void.

${ }^{171}$ Christ for all Nations v. Appolo Insurance Co. Ltd. [1999] LLR. 1635. In this case, the Kenyan High Court observed that the notion of public policy covers those awards which are inconsistent with the Kenyan Constitution. ${ }^{172}$ Lacking precedent, [in defining public policy] the court can always be guided by that light and the principles underlying the Fundamental Rights and the Directive Principles enshrined in our Constitution.

173 Oberlandesgericht Karlsruhe, 10 Schedule 04/01 available at www./dis-arb.de/de/47datenhanken/rspr/orgkarlsruhe-az-10-sch-04-01-datum-2001-09-14-id1268 (accessed September 2019).

174 Riyadh Arab Agreement for Judicial Cooperation states in a similar tone in the following words: 'Recognition of judgments shall be refused in the following cases: (a) if recognition would be in contradiction with the stipulations of the Islamic Shari'a...'

175 Grosvenor Casine Ltd. v. Abdul Malik Badruddin, PLD 1998 Karachi 104.

176 Under section 44-A of the Code of Civil Procedure, 1908 a decree of any superior Courts of the United Kingdom or any reciprocating territory may be executed in Pakistan as if it had been passed by the District Court [of Pakistan]. 177 This principle is, in fact, based on the constitutional mandate found in Article 227 of the Constitution which states, 'All existing laws shall be brought in conformity with the Injunctions of Islam as laid down in the Holy Qur'an and Sunnah ... and no law shall be enacted which is repugnant to such Injunctions'. 
e.g., the Interest Act 1839. Islamic law acknowledges the rights of non-Muslim to enter into contract in accordance with their own religious practices without taking into consideration the prohibition and authorization of Islamic law. They may enter into a contract of wine and the resultant award can be enforced between them. ${ }^{178}$ However, if one of the parties is Muslim then Islamic law will apply and such award based on the contract of selling or buying of wine or any other contract prohibited in Islamic law cannot be enforced because of its being against the Islamic public policy. ${ }^{179}$

\section{CONCLUSION}

Public policy, in general, comprises those principles which a State jealously protect in order to guard its morality; preserve social, political, economic order and discharge its obligation towards the other states. Public policy and its contours are not defined in any statute of any country in the Indian subcontinent as is the case in most countries surveyed by the recent IBA study (2015) mentioned above. In order to understand public policy one has to glean it from the provisions of the Constitution, laws and precedents of the courts. However, before applying those principles found in the aforesaid sources, the mandatory principles are needed to be distinguished from those of directory or dispositive ones. Public policy is based upon only those mandatory principles which are foundational, of substratal values and principles forming the bedrock of laws.

In the Indian subcontinent, the public policy concept has a common heritage, same meaning but a different approach (especially, in Pakistan which includes principles of the Qur'an and the Sunnah in the domain of public policy). Pakistan and India are among those countries which interpret public policy as public policy of the respective countries, as against the concept of international public policy being preached by the International Law Association, thus these follow the conceptual principle of the monist approach. Further, there seems to be the main apparent hurdle to the application of concept of international public policy in Pakistan, like many other Muslim countries, in regard to the applicability of principles of Shari'ah.

In this study, it will be noticed that though India, Pakistan and Bangladesh inherited the common legal tradition from the English legal system, i.e., the English common law, in their respective territories the trajectory of the appreciation and application of the concept of public policy in the case law may not be always found uniform nor, for that matter, within the English case law itself from the historical point of view. It is true that with the change of times, values change, societal expectations evolve, so does public policy. It appears often to be the case that public policy is better understood in a given time-frame and context at the domestic or the international level. The public policy notion may play different roles in international commercial arbitration and international investment arbitration though having had commonalities occasionally in the two spheres. In the latter, with more scientific advancement and consequent better understanding of the environment and climate change issues for example,

\footnotetext{
178 Jalal El-Ahdab, Arbitration with the Arab Countries (The Hague: Kluwer Law International, 2011), pp. 1-52.

179 Ibid.
} 
many new rules of public policy may play their roles in the foreseeable future both at the domestic and international levels which will have an impact on international arbitration. However, there is an expectation that the vagaries of the notion of public policy should not be allowed to jeopardise the justice of any form, including arbitral, and there should be always the restrictive approach to public policy so that it does bolt as an unruly horse. 